\title{
HUBUNGAN ANTARA KEHARMONISAN DALAM KELUARGA DENGAN KONSEP DIRI PADA REMAJA KELAS X DAN XI DI SMA NEGERI 2 SIBORONGBORONG
}

\author{
Ester Lia Siahaan \\ Istiana, S.Psi. M.Pd \\ Syafrizaldi, S.Psi, M.Si \\ Fakultas Psikologi Universitas Medan Area
}

\begin{abstract}
ABSTRAK
Penelitian ini bertujuan untuk melihat hubungan antara keharmonisan dalam keluarga dengan konsep diri pada remaja. Subjek dalam penelitian ini adalah siswa-siswi kelas X dan XI SMA Negeri 2 Siborongborong. Hipotesis yang dikemukakan peneliti adalah adanya hubungan yang positif antara keharmonisan dalam keluarga dengan konsep diri remaja, artinya semakin harmonisa suatu keluarga maka konsep dirinya akan semakin positif atau baik, sebaliknya semakin tidak harmonis suatau keluarga maka konsep dirinya akan semakin negative atau kurang baik. Skala yang digunakan dalam penelitian ini adalah skala konsep diri yang dibuat berdasarkan aspek yang dikemukakan oleh Berzonsky (1998), yaitu aspek fisik, aspek sosial, aspek moral dan aspek psikis.Skala keharmonisan dalam keluarga dibuat berdasarkan aspek-aspek yang dikemukakan oleh Gunarsa (2000), yaitu kasih sayang antara anggota keluarga, saling pengertian sesama anggota keluarga, komunikasi yang baik didalam keluarga, dan kerjasama antara anggota keluarga. Sampel yang digunakan dalam penelitian ini berjumlah 100 orang yaitu siswa-siswi kelas X dan XI di SMA Negeri 2 Siborongborong. Teknik analisis yang digunakan adalah korelasi product moment. Berdasarkan hasil analisis diperoleh hasil (1) ada hubungan positif yang signifikan antara keharmonisan dalam keluarga dengan konsep diri yang dilihat dari $r_{x y}=0,370 ; p=0,000(p<0,05)$, (2) sumbangan keharmonisan dalam keluarga terhadap konsep diri adalah 13,7 \% diketahui dari $r^{2}=0,137$. (3) konsep diri remaja kelas $X$ dan XI SMA Negeri 2 Siborongborong tergolong sangat tinggi dan keharmonisan dalam keluarganya juga sangat tinggi.
\end{abstract}

Kata kunci :Konsep Diri, Keharmonisan Keluarga, Remaja PENDAHULUAN

Banyak masalah yang dijumpai pada Hurlock menyebut masa remaja dengan istilah adolescene yang dalam bahasa latin berarti remaja yang tumbuh menjadi dewasa. Secara lebih luas adolescene adalah proses berkembangnya kematangan mental, emosional, dan fisik seorang manusia. Hurlock mengatakan bahwa rentang pada masa ini tidak memiliki tempat yang jelas, karena tidak bisa dimasukkan ke dalam kelompok anak-anak, tidak pula disebut dewasa atau tua.Semakin mendekatnya usia kematangan, para remaja semakin gelisah untuk memberikan kesan bahwa mereka sudah hampir dewasa. masa remaja, baik dari lingkungan keluarga, masyarakat maupun teman sebaya.Mappiare (dalam Maulani, 2007) menyatakan bahwa adapun masalah yang dihadapi remaja manurut intensitasnya adalah masalah wajar, masalah menengah yang bersangkutan dengan tanda-tanda bahaya dan masalah bertaraf kuat yang meliputi masalah yang pasif dan masalah yang agresif.Ada juga masalah yang berhubungan dengan ciri sendiri atau pribadi remaja itu sendiri dan masalah yang berhubungan dengan orang tua serta masalah yang berhubungan dengan masyarakat luas. 
Lebih lanjut Mappiare (dalam Maulani, 2007) mengungkapkan salah satu masalah yang sering dijumpai di lingkungan keluarga adalah remaja ingin bebas, menentukan tujuan hidupnya sendiri, sementara orang tua masih takut memberikan tanggung jawab pada remaja. Remaja ingin diakui sebagai orang dewasa sementara orang tua masih tidak melepaskannya sebab belum cukup diberi kebebasan. Kebutuhan akan perhatian dan kasih sayang dari orang tua tidak selamanya dapat terpenuhi karena antara lain kesibukan dalam soal ekonomis orang tuanya. Tekanan dari orang tua dimana anak harus mengikuti keinginan orang tua terutama dalam hal pelajaran, dan perselisihan antara sesama saudara.

Dalam hal ini orang-orang terdekat adalah termasuk keluarga. Hal ini jelas berkaitan dengan konsep diri mereka yang dimunculkan dalam perilakunya sehari-hari dimana bahwa siswa siswi di sekolah tersebut cenderung memiliki konsep diri yang negatif, dengan ciri-ciri: peka terhadap kritik. Kurangnya kemampuan untuk menerima kritik dari orang lain sebagai proses refleksi diri, individu responsif sekali terhadap pujian yang diberikan oleh orang lain pada dirinya, individu cenderung merasa tidak disukai oleh orang lain. Perasaan subjektif bahwa setiap orang disekitarnya memandang dirinya negatif, individu cenderung merasa tidak disenangi oleh orang lain, individu bersikap pesimis terhadap kompetisi, keengganannya untuk bersaing dengan orang lain dalam membuat prestasi, mengalami hambatan dalam berinteraksi dengan orang lain atau sosialnya karena merasa kurang mampu dan kurang percaya diri.

Sedangkan konsep diri yang positif mempunyai cirri-ciri sebagai berikut: dapat menerima dan mengenal dirinya dengan baik, dapat menyimpan informasi tentang dirinya sendiri baik informasi yang positif maupun negatif, apabila mereka memiliki pengharapan selalu merancang tujuan-tujuan yang sesuai dan realistis, individu menyadari bahwa tiap orang memiliki perasaan, keinginan, dan perilaku yang berbeda. Peneliti melakukan penelitian ini karena ingin mengetahui apakah konsep diri di SMA Negeri 2 Siborongborong ini tergolong baik atau tidak dan seberapa besar pengaruh keharmonisan dalam keluarga terhadap konsep diri pada remaja disekolah tersebut.

\section{KAJIAN PUSTAKA}

Remaja

Remaja berasal dari kata latinadolensence yang berarti tumbuh atau tumbuh menjadi dewasa. Istilah adolensence mempunyai arti yang lebih 
luas lagi yang mencakup kematangan mental, emosional sosial dan fisik (Hurlock, 1996).Remaja sebenarnya tidak mempunyai tempat yang jelas karena tidak termasuk golongan anak tetapi tidak juga golongan dewasa atau tua.Lebih lanjut Hurlock menjelaskan masa remaja adalah masa dimana munculnya berbagai kebutuhan dan emosi serta tumbuhnya kekuatan dan kemampuan fisik yang lebih jelas dan daya fikir yang matang.Hurlock (1996) membagi masa remaja menjadi masa remaja awal (13 tahun hingga 16 tahun) dan masa remaja akhir (16 tahun hingga 18 tahun).Masa remaja awal dan akhir dibedakan oleh Hurlock karena pada masa remaja akhir individu telah mencapai transisi perkembangan yang lebih mendekat masa dewasa.Santrock (2003,) mengatakan bahwa perkembangan pada remaja merupakan proses untuk mencapai kematangan dalam berbagai aspek sampai tercapai tingkat kedewasaan. Proses ini adalah sebuah proses yang memperlihatkan hubungan antara perkembangan aspek fisik dan psikis pada remaja.

Pada usia atau fase remaja, tugastugas perkembangan yang harus dipenuhi adalah sebagi berikut (Havighurst dalam Ali dan Asrori,2011):
1. Mencapai hubungan yang baru yang lebih matang dengan teman sebaya baik pria maupun wanita.

2. Mencapai peran sosial pria dan wanita.

3. Menerima keadaan fisik dan menggunakannya secara efektif.

4. Mencari kemandirian emosional dari orangtua dan orang-orang dewasa lainnya.

5. Mencapai jaminan kebebasan ekonomis.

6. Memilih dan menyiapkan lapangan pekerjaan.

7. Mempersiapkan diri untuk memasuki kehidupan keluarga.

8. Mengembangkan keterampilan intelektual dan konsep-konsep yang penting untuk kompetensi kewarganegaraan.

9. Mencapaidan mengharapkan tingkah laku sosial yang bertanggung jawab.

10. Memperoleh suatu himpunan nilainilai dan sistem etika sebagai pedoman tingkah laku.

\section{Konsep Diri}

Konsep diri adalah semua ide, pikiran, kepercayaan, dan pendirian yang diketahui individu tentang dirinya dan mempengaruhi individu dalam berhubungan dengan orang lain (Stuart dan Sundeen, 1998). Hal ini termasuk persepsi individu akan sifat dan kemampuannya, interaksi dengan orang 
lain dan lingkungan, nilai-nilai yang berkaitan dengan pengalaman dan objek, tujuan serta keinginannya.

Konsep diri merupakan hal yang penting dalam kehidupan sebab pemahaman seseorang mengenai konsep dirinya akan menentukan dan mengarahkan perilaku dalam berbagai situasi. Jika konsep diri seseorang negatif, maka perilaku seseorang tersebut akan bersifat negatif, sebaliknya jika konsep diri seseorang positif maka perilaku seseorang tersebut akan bersifat positif (fits dan Shavelson, dalam Yanti, 2000).Konsep diri juga merupakan gambaran mental diri sendiri yang terdiri dari pengetahuan tentang diri sendiri, pengharapan diri dan penilaian terhadap diri sendiri.Selanjutnya menurut Rahmat (2000) kosep diri adalah pandangan dan perasaan kita, persepsi ini boleh bersifat psikologis, sosial, dan psikis.Konsep diri bukan hanya gambaran deskriptif, tetapi juga penilaian kita.Sementara itu Hurlock (1996) menyatakan bahwa yang dimaksud dengan konsep diri adalah kesan individu mengenai karakteristik dirinya, yang mencakup karakteristik fisik, sosial, emosional, aspirasi dan achievement.

Faktor-faktor yang mempengaruhi konsep diri yaitu :

1. Usia

2. Keharmonisan dalam keluarga
3. Inteligensi

4. Orang lain

5. Jenis kelamin, ras dan status sosial ekonomi

6. Pendidikan

Menurut Berzonsky (1998), untuk memahami konsep diri seseorang dilihat melalui empat aspek yaitu :

1. Aspek diri fisik (psysical self), melalui penilaiannya seseorang terhadap keadaan fisik yang dimilikinya, antara lain : tubuh, pakaian dan benda yang dimilikinya.

2. Aspek diri sosial (social self), meliputi peranan sosial yang dimainkan individu dan sejauhmana penilaian individu terhadap performancenya.

3. Aspek diri moral (moral self), meliputi nilai-nilai prinsip yang memberikan arti bagi kehidupan individu.

4. Aspek diri psikis (psychological self),meliputi pikiran-pikiran, perasaan-perasaan dan sikap individu terhadap dirinya.

\section{Keharmonisan Keluarga}

Menurut Gunarsa (2000) keluarga harmonis adalah bilamana seluruh anggota keluarga merasa bahagia yang ditandai oleh berkurangnya ketegangan, kekecewaan dan menerima seluruh keadaan dan keberadaan dirinya (eksistensi, aktualisasi diri) yang meliputi 
aspek fisik, mental dan sosial.Hawari (dalam Moeslim, 2006) menambahkan bahwa keharmonisan keluarga itu akan terwujud apabila masing-masing unsur dalam keluarga itu dapat berfungsi dan berperan sebagaimana mestinya dan tetap berpegang teguh pada nilai-niali agama kita, maka interaksi sosial yang harmonis antar unsur dalam keluarga itu akan dapat diciptakan.

Menurut Hawari (dalam Moeslim,

2006) keharmonisan dalam keluarga dapat tercapai melalui hubungan perkawinan bahagia yang memiliki ciriciri diantaranya :

1. Menciptakan kehidupan beragama dalam keluarga

2. Mempunyai waktu bersama keluarga

3. Mempunyai komunikasi yang baik antar anggota keluarga

4. Saling menghargai antar sesama anggota keluarga

5. Adanya hubungan atau ikatan yang erat antar anggota keluarga

Menurut Gunarsa (2000) ada beberapa aspek keharmonisan keluarga adalah :

1. Kasih sayang antar anggota keluarga Anggota keluarga menunjukkan saling menghargai dan saling menyayangi, mereka bisa merasakan betapa baiknya keluarga.Anggota keluarga mengekspresikan penghargaan dan kasih sayang secara jujur.Penghargaan itu mutlak diperlukan, karena dengan demikian masing-masing anggota merasa sangat dicintai dan diakui keberadaannya.

2. Saling pengertian sesama anggota keluarga

Selain kasih sayang, pada umumnya para remaja sangat mengharapkan pengertian dari orangtuanya. Dengan adanya saling pengertian maka tidak akan terjadi pertengkaranpertengakaran antar sesama anggota keluarga.

3. Dialog atau komunikasi efektif yang terjalin di dalam keluarga

Anggota keluarga mempunyai keterampilan berkomunikasi dan banyak waktu digunakan untuk itu. Dalam keluarga harmonis ada beberapa kaidah komunikasi yang baik, antara lain :

a. Menyediakan cukup waktu

b. Mendengarkan

c. Pertahankan kejujuran

4. Mempunyai waktu bersama dan kerjasama dalam keluarga

Keluarga menghabiskan waktu (kualitas dan kuantitas waktu yang besar) di antara mereka.Kebersamaan di antara mereka sangatlah kuat, namun tidak mengekang.Selain itu, kerjasama yang baik antara sesama anggota keluarga juga sangat dibutuhkan dalam kehidupan seharihari. Saling membantu san gotong 
royong akan mendorong anak untuk bersifat toleransi jika kelak bersosialisasi dalam masyarakat.

Gunarsa (2001) menyatakan bahwa suasana rumah dapat mempengaruhi keharmonisan keluarga.Suasana rumah adalah kesatuan yang serasi anatara pribadi-pribadi, kesatuan yang serasi antara orangtua dan anak. Jadi suasana rumah yang menyenangkan akan tercipta bagi anak bila terdapat kondisi :

1. Anak dapat merasakan bahwa ayah dan ibunya terdapat saling pengertian dan kerjasama yang serasi serta saling mengasihi antara satu dengan yang lainnya.

2. Anak dapat merasakan bahwa orangtuanya mau mengerti dan dapat menghayati pola perilakunya, dapat mengerti apa yang diinginkannya, dan memberi kasih sayang secara bijaksana.

3. Anak dapat merasakan bahwa saudara-saudaranya, mau memahami dan menghargai dirinya menurut kemauan, dan citan-citanya, dan anak dapat merasakan kasih sayang yang diberikan saudara-saudaranya.

\section{Hipotesis}

Hipotesis dalam penelitian ini adalah ada hubungan positif antara keharmonisan dalam keluarga dengan konsep diri pada remaja di SMA Negeri 2 Siborongborong. Diasumsikan bahwa semakin harmonis keluarga maka semakin tinggi konsep diri pada remaja. Demikian sebaliknya, semakin tidak harmonis keluarga maka akan semakin rendah konsep diri pada remaja.

\section{METODE PENELITIAN}

Penelitian ini menggunakan pendekatan kuantitatif jenis deskriptif dan asosiatif.

Populasi yang digunakan peneliti adalah seluruh siswa- siswi kelas I dan II di SMA Negeri 2 siborongborong dengan jumlah 582 orang, yang terdiri dari kelas I dengan jumlah 284 orang dan kelas II dengan jumlah 298 orang.Dalam penelitian ini,teknik pengambilan sampel yang digunakan adalah teknik sampel kuota (quota sample) yaitu teknik pengambilan data berdasarkan jumlah yang sudah ditentukan dan yang penting terpenuhinya jumlah atau kuota yang telah ditetapkan.Sampel penelitian ini ditentukan oleh pihak sekolah tempat peneliti melakukan penelitian dengan jumlah $25 \%$ dari jumlah populasi. Jadi jumlah sampel yang digunakan adalah 100 orang.

Metode yang digunakan untuk mengumpulkan data adalah skala psikologi dalam bentuk likert.Skala yang dimaksud adalah skala konsep diri yang disusun berdasarkan aspek-aspek konsep diri menurut Berzonsky, danskala keharmonisan keluarga yang disusun 
berdasarkan aspek-aspek keharmonisan keluarga menurut Gunarsa.Nilai skala setiap pernyataan diperoleh dari jawaban subjek yang menyatakan mendukung (favourable) atau tidak mendukung (unfavourable) terhadap setiap pernyataan dalam empat kategori jawaban yakni sangat sesuai (SS), sesuai (S), tidak sesuai (TS), sangat tidak sesuai (STS).

\section{Teknik Analisis Data}

Penelitian ini menggunakan analisis statistik untuk menguji hipotesis yang berorientasi korelatif, yaitu melihat hubungan antara keharmonisan keluarga denga konsep diri, maka digunakan teknik korelasi product moment dari pearson (Azwar, 2007) dengan rumus sebagai berikut :

$$
r y=\frac{\sum x-\frac{\left(\sum x\right)\left(\sum y\right)}{N}}{\sqrt{\left\{\sum x^{2}-\frac{\left(\sum x\right)^{2}}{N}\right\}\left\{y^{2}-\frac{\left(\sum y\right)^{2}}{N}\right\}}}
$$

Keterangan :

$r_{x y=}$ koefisien korelasi antara $\mathrm{x}$ dan $\mathrm{y}$

$\sum_{x}=$ keharmonisan keluarga

$\Sigma_{y}=$ konsep diri

$\sum x^{2}=$ jumlah kuadrat skor $\mathrm{x}$

$\sum y^{2}=$ jumlah kuadrat skor y

$\mathrm{N}=$ jumlah subjek

Sebelum data dianalisis dengan teknik korelasi product moment, maka terlebih dahulu uji asumsi penelitian, yaitu uji normalitasuntuk mengetahui apakah pada distribusi data penelitian masing-masing variabel telah menyebar secara normal, dan uji linieritas untuk mengetahui apakah antara variabel keharmonisan keluarga memiliki hubungan secara linier dan membentuk garis lurus terhadap variabel konsep diri. Semua data dianalisis menggunakan SPSS.

\section{HASIL DAN PEMBAHASAN}

\section{Uji Asumsi}

\section{a. Uji Normalitas Sebaran}

Uji normalitas sebaran dianalisis dengan menggunakan uji normalitas sebaran data penelitian menggunakan teknik Kolmogrov-Smirnov Test for normality. Berdasarkan analisis tersebut, maka diketahui bahwa konsep diri dan dkeharmonisan dalam keluarga mengikuti sebaran normal yang berdistribusi sesuai dengan prinsip kurva normal. Sebagai kriterianya apabila p>0,05 maka sebarannya dikatakan normal, sebaliknya apabila p $<0,05$ sebarannya dinyatakan tidak normal (Hadi dan Pamardingsih, 2000). Hasil uji normalitas menunjukkan skor kolmogrov - Smirnov variable konsep diri sebesar 1, 080 dengan $p=(p>0,05)$, yang berarti variabel konsep diri memiliki data yang berdistribusi normal. Variabel keharmonisan dalam keluarga juga memiliki distribusi data yang normal 
denga skor sebesar 0,638 dengan $\mathrm{p}=$ $0,200(\mathrm{p}>0,05)$

Tabel 1. Rangkuman Hasil perhitunganUji Normalitas Sebaran

\begin{tabular}{|c|c|c|c|c|c|}
\hline Variabel & Rerata & K-S & SB & P & Ket \\
\hline Keharmo & 134.4 & 1.080 & 13.5 & 0,200 & Norma \\
nisan & 7 & & 8 & & 1 \\
keluarga & & & & & \\
\hline $\begin{array}{c}\text { Konsep } \\
\text { diri }\end{array}$ & 118.6 & 0,638 & 11.5 & 0,200 & Norma \\
& & 6 & & 1 \\
\hline
\end{tabular}

Keterangan :

Rerata : Nilai rata-rata

K-S : Koefisien Normal KolmogrovSmirnov

SB :Simpangan Baku (Standart Deviasi)

$\mathrm{P}$ : Peluang terjadinya kesalahan

\section{Uji Homogenitas Varians}

Berdasarkan uji linieritas dapat diketahui apakah variabel bebas dan variabel terikat dapat atau tidak dianalisis secara korelasional.Hasil analisis menunjukkan bahwa variabel bebas (keharmonisan dalam keluarga) mempunyai hubungan yang linieritas terhadap variabel terikat (konsep diri).Sebagai kriterianya, apabila $\mathrm{p}<0,05$ maka dinyatakan mempunyai derajat hubungan yang linear (Hadi dan Pamardingsih, 2000). Uji linearitas hubungan antara variabel keharmonisan dalam keluarga terhadap konsep diri menghasilkan $\mathrm{F}=15.637$ dengan nilai signifikansi $\mathrm{p}=0,000 \quad(\mathrm{p}<0,01)$ yang menunjukkan adanya hubungan linear antara variabel keharmonisan dalam keluarga terhadap konsep diri
Tabel 2. Rangkuman Hasil Perhitungan Uji LinieritasHubungan

\begin{tabular}{|c|c|c|c|c|}
\hline $\begin{array}{c}\text { Korela } \\
\text { sional }\end{array}$ & F Beda & P Beda & Ket & $\begin{array}{c}\text { Korelasi } \\
\text { onal }\end{array}$ \\
\hline $\mathrm{X}-\mathrm{Y}$ & 15,637 & 0,000 & Linear & $\mathrm{X}-\mathrm{Y}$ \\
\hline
\end{tabular}

Keterangan :

$\mathrm{X} \quad$ : Keharmonisan Dalam Keluarga

Y : Konsep Diri

F Beda : Koefisien Linearitas

P Beda : Proporsi peluang ralat Alpha untuk F Beda

Hasil Perhitungan Korelasi R Product Moment

Berdasarkan hasil perhitungan korelasi $\mathrm{r}$ product moment diketahui bahwa terdapat hubungan positif yang sangat signifikan antara keharmonisan dalam keluarga dengan konsep diri pada remaja di SMA Negeri.2 Siborongborong $\left(r_{x y}=0,370\right.$ dengan $\left.\mathrm{p}=0,000 ; \mathrm{p}>0,05\right)$. Hal ini berarti bahwa semakin baik keharmonisan dalam keluarga semakin baik konsep diri pada remaja di SMA Negeri.2 Siborongborong, dan sebaliknya semakin buruk keharmonisan dalam keluarga maka akan semakin buruk juga konsep diri pada remaja di SMA Negeri.2 Siborongborong.

Koefisien determinasi keharmonisan dalam keluarga dengan konsep diri ditunjukkan dengan $\mathrm{R}$ square sebesar 0,137 . Angka 0,137 mengandung arti bahwa dalam penelitian, keharmonisan dalam keluarga memiliki sumbangan efektif sebesar $13,7 \%$.

Tabel 3.Rangkuman Hasil Analisis Korelasi r Product Moment 


\begin{tabular}{|c|c|c|c|c|c|}
\hline Satistik & $\begin{array}{c}\text { Koefisien } \\
\left(r_{x y}\right)\end{array}$ & $\begin{array}{c}\text { Koefisien } \\
\text { determinan }\left(r^{2}\right)\end{array}$ & $\mathrm{P}$ & $\begin{array}{c}\text { BE } \\
\%\end{array}$ & Keterangan \\
\hline X-Y & 0,370 & 0,137 & 0,000 & $\begin{array}{c}13,7 \\
\%\end{array}$ & Signifikan \\
\hline
\end{tabular}

Keterangan :

$\mathrm{X}$ : Keharmonisan dalam keluarga

$\mathrm{Y} \quad$ : Konsep diri

$r_{x y}:$ Koefisien Korelasi antara variabel $\mathrm{X}$ terhadap Y

$r^{2}$ : Koefisien determinan $\mathrm{X}$ terhadap $\mathrm{Y}$

$\mathrm{P} \quad$ : Peluang terjadinya kesalahan

BE\% : Bobot Sumbangan efektif X terhadap Y dalam persen

Ket : Sangat signifikan pada taraf signifikan $1 \%$ atau $\mathrm{p}>0,01$

Tabel 4. Rangkuman

Perhitungan Statistik Induk

\begin{tabular}{|c|c|c|c|c|}
\hline Variabel & Mean & SD & N & Variabel \\
\hline $\mathrm{X} 1$ & 134.47 & 13.58 & 100 & $\mathrm{X} 1$ \\
\hline
\end{tabular}

Keterangan :

$\mathrm{X} 1 \quad$ : Keharmonisan dalam keluarga

X2 : Konsep diri

Rerata : Nilai Rata-rata

SD : Standart Deviasi

\section{Hasil Perhitungan Mean Hipotetik dan}

\section{Mean Empirik}

\section{a. Mean Hipotetik}

Jumlah butir yang dipakai dalam mengungkapkan variabel konsep diri adalah 38 sebanyak butir yang diformat dengan skala Likert dalam empat pilihan jawaban, maka mean hipotetiknya = $\{(38 \mathrm{x} 1)+(38 \mathrm{x} 4)\}: 2=190: 2=$ 95.Jumlah butir yang dipakai dalam mengungkapkan variabel keharmonisan dalam keluarga adalah 40 sebanyak butir yang diformat dengan skala likert dalam empat pilihan jawaban, maka mean hipotetiknya $=\{(40 \times 1)+(40 \times 4)\}=200:$ $2=100$.

\section{b. Mean Empirik}

Skor total keseluruhan subjek untuk konsep diri adalah 14809 dengan jumlah subjek 100 orang, maka mean empiriknya $=14809: 100=148,09$. Skor total keseluruhan subjek untuk keharmonisan dalam keluarga adalah 13209 dengan jumlah subjek 100 orang, maka mean empiriknya $=13209: 100=132,09$.

\section{c. Kriteria}

Untuk variabel konsep diri, apabila mean hipotetik <mean empirik maka subjek penelitian memiliki konsep diri yang baik, sedangkan apabila mean hipotetik >mean empirik maka subjek penelitian memiliki konsep diri yang buruk.Untuk variabel keharmonisan dalam keluarga, apabila mean hipotetik <mean empirik maka subjek penelitian memiliki keharmonisan dalam keluarga yang baik, sedangkan apabila mean hipotetik >mean empirik maka subjek penelitian memiliki keharmonisan dalam keluarga yang tidak baik.Berdasarkan perbandingan kedua mean di atas, mean hipotetik dan mean empirik maka diketahui bahwa Remaja di SMA Negeri.2 yang dijadikan subjek penelitian memiliki konsep diri yang baik dan memiliki keluarga yang cukup harmonis.

Tabel 5. Hasil Perhitungan Nilai RataRata Hipotetik dan Nilai Rata-rata Empirik 


\begin{tabular}{l|c|c|c|c|}
\hline \multirow{2}{*}{ Variabel } & \multicolumn{2}{|c|}{ Nilai Rata-Rata } & SD & KET \\
\cline { 2 - 3 } & Hipotetik & Empirik & & \\
\hline Konsep diri & 95 & 148,09 & 13,58 & $\begin{array}{c}\text { Sangat } \\
\text { baik }\end{array}$ \\
\hline $\begin{array}{l}\text { eharmonisan } \\
\text { lam keluarga }\end{array}$ & 100 & 132,09 & 11,56 & $\begin{array}{c}\text { Sangat } \\
\text { baik }\end{array}$ \\
\hline
\end{tabular}

Berdasarkan analisis product moment diperoleh bahwa terdapat hubungan positif yang signifikan antara keharmonisan dalam keluarga dengan konsep diri pada Remaja di SMA Negeri 2 Siborongborong dengan koefisien korelasi $r_{x y}=0,370 ; \mathrm{p}=0,000$; berarti $\mathrm{p}$ $=<0,05$ yang berarti sangat signifikan. Hal ini menunjukkan bahwa ada hubungan yang positif antara keharmonisan dalam keluarga dengan konsep diri pada remaja di SMA Negeri 2 Siborongborong, sehingga hipotesis yang diajukan dalam penelitian ini diterima.

Berdasarkan pada hasil penelitian diatas sejalan dengan pernyataan bahwa lingkungan pertama yang memberikan pengaruh mendalam pada diri adalah lingkungan keluarganya sendiri dan orangtua menjadi factor penting dalam menanamkan dasar kepribadian yang ikut menentukan corak dan gambaran kepribadian seseorang setelah dewasa (Gunarsa, 1999).

Konsep diri tidak dibawa sejak lahir tetapi secara bertahap sedikit demi sedikit timbul sejalan dengan berkembangnya kemampuan persepsi individu. Konsep diri manusia terbentuk melalui proses belajar sejak masa pertumbuhan seseorang dari kecil hingga dewasa. Bayi yang baru lahir tidak mmiliki konsep diri karena mereka tidak mampu membedakan dirinya dengan lingkungannya. Lingkungan, pengalama, dan pola asuh orangtua turut memberikan pengaruh yang signifikan terhadap konsep diri yang terbentuk. Sikap atau respon orangtua dan lingkungan kan menjadi informasi bagi anak untuk menilai siapa dirinya.

Keharmonisan dalam keluarga memberikan pengaruh yang signifikan sebesar $13,7 \%$ terhadap konsep diri, dan masih terdapat $86,3 \%$ dipengaruhi oleh faktor-faktor lain yang tidak diikutkan dalam penelitian ini misalnya, usia, inteligensi, orang lain dan pendidikan. Hasil penelitian ini sesuai dengan yang dikemukakanPudjijogyanti menjelaskan bahwa kondisi keluarga yang kurang kondusif (kurang mendukung) dalam keberlangsungan interaksi yang sehat dapat menyebabkan konsep diri yang rendah. Dimana Keharmonisan keluarga dapat terlihat dan tercermin dari sikap dan pandangan akan hidup, kegemaran dan pola kepribadian para anggota di dalamnya.Dengan demikian dapat ditegaskan bahwa keharmonisan keluarga berhubungan erat dengan konsep diri. Oleh karena itu orangtua perlu menciptakan suasana kehidupan keluarga yang harmonis untuk 
mengembangkan konsep diri agar anak mempunyai pandangan yang positif terhadap dirinya, mampu menyesuaikan diri dengan baik dan menjadi lebih mandiri.

Keluarga harmonis adalah bilamana seluruh anggota keluarga merasa bahagia yang ditandai oleh berkurangnya ketegangan, kekecewaan dan menerima seluruh keadaan dan keberadaan dirinya (eksistensi, aktualisasi diri) yang meliputi aspek fisik, mental dan sosial. Keluarga yang harmonis akan memberikan dampak yang positif terhadap konsep diri pada remaja.

Hasil penelitian yang diperoleh dari penelitian ini, yakni bahwa remaja di SMA Negeri 2 Siborongborong memiliki atau berasal dari keluarga yang harmonis atau baik karena memberi pengaruh pada pertumbuhan konsep diri yang baik. Sebab pada keharmonisan dalam keluarga dapat dilihat nilai empirik sebesar 132,09 lebih besar daripada nilai rata-rata hipotetiknya yakni 100 . Demikian pula halnya dengan konsep diri, nilai rata-rata empiriknya 148,09 lebih besar daripada nilai rata-rata hipotetiknya yakni 95. Dalam penelitian ini jelas terlihat perbedaan antara hasil penelitian dengan fenomena, dimana fenomena awal yang dijelaskan oleh peneliti adalah bahwasannya siswa-siswi tersebut memiliki konsep diri yang rendah atau tidak baik dan berbeda jauh dengan hasil penelitian yang menyatakan bahwa konsep diri dan keadaan didalam keluarga atau keharmonisan dalam keluarga yang dimiliki oleh sampel tersebut adalah baik, hal ini dikarenakan adanya faktor-faktor lain yang mempengaruhi konsep diri pada remaja tersebut yaitu usia, pendidikan, teman sebaya, lingkungan, dan lain-lain.

\section{PENUTUP}

\section{Kesimpulan}

Terdapat hubungan positif yang sangat signifikan antara keharmonisan dalam keluarga dengan konsep diri pada remaja. Hasil ini dibuktikan dengan koefisien korelasi 0,$370 ; \mathrm{p}=0,000$; berarti $\mathrm{p}=<0,05$. Artinya semakin harmonis sebuah keluarga maka semakin baik konsep diri yang dimiliki oleh remaja di SMA Negeri 2 Siborongborong, sebaliknya semakin buruk keadaan sebuah keluarga maka akan semakin buruk juga konsep diri yang dimiliki oleh remaja di SMA Negeri 2 Siborongborong. Dengan demikian maka hipotesis yang telah diajukan dalam penelitian ini diterima.

Keharmonisan dalam keluarga memberikan pengaruh sebesar $13,7 \%$ terhadap konsep diri, dan masih terdapat $86,3 \%$ dipengaruhi oleh faktor-faktor lain. Faktor lain yang mempengaruhi konsep diri adalah lingkungan teman 
sebaya, usia, dan faktor lain penelitian yang tidak dilihat sikap hidup, tanggung jawab, kepercayaan diri ,kemampuan menyesuaikan diri.

\section{Remaja di SMA Negeri.2} Siborongborong memiliki keharmonisan dalam keluarga yang sangat baik dengan konsep diri yang baik. Sebab pada keharmonisan dalam keluarga dapat dilihat dari nilai empirik sebesar 132,09 lebih besar daripada nilai rata-rata hipotetiknya yakni 100. Demikian pula halnya dengan konsep diri, nilai rata-rata empiriknya 148,09 lebih besar daripada nilai rata-rata hipotetiknya yakni 95.

\section{Saran}

Saran Kepada Siswa Siswi di SMA Negeri 2 Siborongborong (Subjek Penelitian)

Sejalan dengan hasil penelitian ini serta setelah mengetahui keadaan dalam keluarga pada seluruh siswa siswi yang menjadi subjek penelitian, maka disarankan kepada para para siswa/I agar menjaga hubungan yang baik dengan semua anggota keluarga, menjaga komunikasi yang baik, saling menyayangi sesama anggota keluarga dan saling terbuka terhadap anggota keluarga agar berdampak baik terhadap individu tersebut dan lingkungan sekitar dan menjaga hubungan yang harmonis yang merupakan salah satu factor penting dalam membentuk konsep diri yang positif.

Saran Kepada Orangtua subjek.Diharapkan kepada para orangtua dari siswa/I tersebut agar memperhatikan kualitas hubungan yang terjalin didalam keluarga, dengan lebih memfokuskan pemberian kasih saying dan perhatian terhadap anak. Karena cara dan perlakuan orangtua dalam memberikan pembelajaran terhadap anak akan turut mempengaruhi konsep diri anak. Orangtua harus mampu memberikan contoh dan pengarhan yang baik bagi anak.

Saran Kepada Pihak SMA Negeri 2 Siborongborong.Perlunya kerjasama antara guru pembimbing denga wali kelas untuk memberikan bimbingan dan perhatian terhadap siswa-siswi yang konsep dirinya rendah.Fungsikan Badan Konseling (BK) yang ada di sekolah untuk lebih aktif dalam menangani siswasiswi yang konsep dirinya rendah dan perilakunya negatif.Misalnya, membantu siswa/I agar memiliki pemahaman terhadap dirinya dan lingkungan, berdasarkan pemahaman tersebut siswa/I diharapkan mampu mengembangkan potensi dirinya secara optimal dan menyesuaikan dirinya dengan lingkungan dengan baik.

Saran Kepada Peneliti selanjutnya.Menyadari bahwa penelitian 
ini masih memiliki banyak kekurangan, maka disarankan kepada peneliti selanjutnya yang ingin melanjutkan penelitian yang sejenis untuk melihat faktor-faktor lain yang diperkirakan mempengaruhi konsep diri seperti usia kematangan, pendidikan, nama atau julukan serta lingkungan teman sebaya dan diharapkan pada peneliti agar lebih mempertimbangkan variabel kontrol pada penelitian selanjutnya.

\section{DAFTAR PUSTAKA}

Ahmadi Abu. 1999. Psikologi Sosial, Jakarta : Rineka Cipta.

Almighwar, M. 2006. Psikologi Remaja, Bandung : Pustaka Setia

Annisa, nova. 2012. Hubungan antara Konsep Diri dan Kematangan Emosi dangan Penyesuaian Diri Istri yang Tinggal Bersama Keluarga Suami. Jurnal psikologi pitutur.Vol 1.No. 1.Hal.59-60.

Arikunto, S. 1996. Prosedur Suatu Pendekatan Praktek, Edisi Revisi III.Jakarta : Rineka Cipta.

Arikunto, S. 2006. Prosedur Penelitian Suatu Pendekatan Praktik, Edisi Revisi VI. Jakarta : Rineka Cipta.

Azwar, 1992.Validitas dan Reliabilitas, Yogyakarta : Sigma Alpha.

Azwar, S. 2001. Penyusunan Skala Psikologi, Yogyakarta : Pustaka Pelajar Offset

Basri, H. 1999. Keluarga Sakinah.Yogyakarta : Pustaka Pelajar

Burns, R.B. 1993. Konsep Diri, Teori Pengukuran, Perkembangan dan

Perilaku,Jakarta : PT. Arcan.
Calhoun. J.F dan Acocella, J.R. 1995.Penyesuaian dan Hubungan

Kemanusiaan,Semarang : IKIP Semarang.

Djamarah, B.S.2004. Pola Komunikasi Orang Tua dan Anak dalam

Keluarga. Jakarta: Rineka Cipta.

Goleman. 2007. Psikologi Komunikasi Dalam Keluarga. Bandung : CV. Remaja Karya.

Gunarsa, $1994 . \quad$ Psikologi Keluarga.Jakarta : PT. BPK. Gunung Tua.

Hadi, S. 1996. Statistik Jilid I. Yogyakarta : Liberty

Hawari. 2006. Marriage Conseling (Konsultasi Perkawinan). Jakarta : Balai Penerbit Fakultas Kedokteran Universitas Indonesia.

Hurlock, $\quad$ E.B. 1992. PsikologiPerkembangan.Penerje mah: Istiwidayanti \& Soedjarwo. Jakarta : Erlangga.

Keliat, B.A.1991. Gangguan Konsep Diri,Bandung : Penerbit Buku Kedokteran.

Mappiare, A. 1982. Psikologi Remaja,Surabaya : Usaha Nasional.

Mufidah. 2008. Psikologi Keluarga Islam.UIN.MALANG PRESS.

Muhibbin, S. M. Ed. 2003. Psikologi Belajar, Bandung : Penerbit. PT. Remaja Posda Karya.

Pudjijogyanti.1995. Profil Perkawinan Perempuan Indonesia. Jurnal 
Perempuan. Jakarta : Yayasan Jurnal Perempuan.

Rakhmat, J. 2001. Psikologi Komunikasi,Jakarta : Remaja Posda Karya.

Santrock, J.W. 2003. Adolescence. Perkembangan Remaja. Edisi Keenam.

Alih bahasa: Dra. Shinto B. Adelar, M.Sc. dan Sherly Saragih, S.Psi.Jakarta: Erlangga

Sarwono, S.W. 2003. Psikologi Remaja,Jakarta : PT Raja Grafindo.

Thalib, Syamsul Bachri. 2010. Psikologi Pendidikan Berbasis Analisis Empiris Aplikatif, Jakarta : Kencana. 